\title{
State anxiety in patients referred to endoscopy unit
}

\author{
Endoskopi ile ilişkili hasta anksiyetesi
}

Adem SEYMEN ${ }^{1}$, Didem SUNAY ${ }^{1}$, Ibrahim BIYIKOĞLU², Levent FILIK²

Departments of, ${ }^{1}$ Family Medicine, ${ }^{2}$ Gastroenterology, Ankara Research Hospital, Ankara

\begin{abstract}
Background and Aims: We aimed to investigate the frequency of state anxiety before endoscopy and the effective factors. Material and Method: A total of 205 patients ( 122 women, 83 men) who were referred to the gastroenterology clinic for endoscopy between August 2008 and February 2009 were included into the study. A questionnaire was completed to assess sociodemographic characteristics and current diseases and Hamilton Anxiety Rating Scale was used to assess state anxiety. Results: State anxiety was determined in $46.8 \%$ of the patients. No significant relations were found between anxiety level and age, marital status, educational level, or monthly income, but significant differences were determined in terms of sex, social security and working status of the patients. Anxiety levels were significantly high in women, patients without health insurance and in unemployed patients. No significant relations were found between anxiety and whether complaints were acute or chronic, patient awareness of the diagnosis, number of previous endoscopies, the type of endoscopy to be applied, or presence of gastrointestinal system cancer in the family; however, history of a previous unsatisfactory endoscopy experience and of psychiatric disease were significantly related to higher anxiety levels. Conclusion: Risk factors contributing to state anxiety in patients referred for endoscopy are psychiatric disease history, female gender and unsatisfactory endoscopy history. When evaluating these factors before applying endoscopy, we must inform patients who have risk factors.
\end{abstract}

Key words: Endoscopy, anxiety, risk factors

\section{INTRODUCTION}

Today, upper and lower gastrointestinal system endoscopies are utilized in a large number of patients, including in outpatient clinics. Thus, increasing diagnostic accuracy rates, decreasing complications, determining patients in the risk groups, increasing the comfort of patients and physicians, and increasing the tolerability of the process are needed.

The patient referred for endoscopy experiences a period of anxiety until the endoscopy process is completed. This anxious situation may be accepted as one of our basic human emotions. All of us feel a level of anxiety in dangerous situations; we feel restless and anxious when sitting in the dental chair, waiting for an examination, and just before boarding a plane or undergoing an operation. This temporary and situational anxiety caused by hazardous conditions that every individual experiences is referred to as 'state anxiety' (1).

State anxiety is a subjective fear that an individual experiences in a stressful situation. In this regard, the anxiety of a patient experienced before applying the endoscopy process is of importance. It was determined in many studies that giving
Giriș ve Amaç: Endoskopik girișim öncesi hastalarda olabilecek anksiyetenin ve ilişkili faktörlerini tanımlamak. Gereç ve Yöntem: Ağustos 2008-Subat 2009 tarihleri arasinda gastrointestinal endoskopi için başvuran 205 (122 kadın, 83 erkek) hasta çalışmaya dahil edildi. Hastaların sosyodemografik özellikleri, yandas hastalikları ve Hamilton anksiyete skalası skorlan incelendi. Bulgular: Hastalarnn \%46.8'inde endoskopi isslemine bağl anksiyete tespit edildi. Yaş, medeni durum, eğitim düzeyi, aylik gelir ile anksiyete derecesi arasında ilisski bulunamadı. Ancak, cinsiyet, sosyal güvenlik ve hastaların çalışma statüsü ile anksiyete decesi arasında ilişsi gözlendi ve kadın cinsiyet, sosyal güvence olmaması ve isssizlerde anksiyete skoru yüksekti. Hastaların yakınmalarının kronik/akut olması, tanıdan haberdar olmaları, daha önceki endoskopi sayısı ve şekilleri, ailede gastrointestinal sistem kanseri varlığı, daha önceki yetersiz endoskopi öyküsü ile anksiyete arasında ilişki bulunamad. Sonuç: Daha önce psikiyatrik sorun olması, kadın cinsiyet ve yetersiz endoskopi öyküsü olan hastalarda hastalara daha fazla bilgilendirme yapılmasının uygun olduğu sonucuna vardık.

Anahtar kelimeler: Endoskopi, anksiyete, risk faktörleri

sufficient information without comprehensive sentences decreases a patient's anxiety before an intervention $(2,3)$. Anxiety levels were found higher in female patients, patients with a history of an unsatisfactory endoscopy, in those with low educational level, and in those undergoing colonoscopy $(2,4-7)$.

In the present study, we aimed to investigate the frequency of state anxiety and related factors in patients who were referred to our endoscopy unit.

\section{MATERIAL AND METHOD}

A total of 205 patients, 122 women and 83 men, who were referred to the gastroenterology clinic for gastroduodenoscopy, colonoscopy or rectoscopy between August 2008 and February 2009 were included into this cross-sectional and observational study. None of the patients was medically sedated or received psychiatric drugs (anxiolytics). Pharynx anesthesia was applied in all patients.

Just prior to the endoscopy procedure, patients were informed about the study and their written consents were obtai- 
ned. A questionnaire inquiring about sociodemographic characteristics, medical history, current disease, and previous endoscopic interventions was then filled.

The Hamilton Anxiety Rating Scale (HARS) was used to assess state anxiety. This widely used interview scale measures the severity of a patient's anxiety based on 14 parameters, including anxious mood, tension, fears, insomnia, somatic complaints, and behavior at the interview (8). Each item is simply given a 5-point score - 0 (not present) to 4 (severe). Scores between 0 and 5 indicate no anxiety, 6 to 14 minor anxiety, and 15 and higher major anxiety. "In recent days" expression was added to each item in order to exclude a possible existing anxiety disorder. Symptoms existing for a long time and expressed by the patient as well as somatic symptoms that may have been related to organic disease of the patient were not included in the scoring.

According to HARS, patients were classified into two groups as 1 ) no anxiety (score $<5$ ) or 2 ) anxiety (score $>5$ ), and these two groups were compared. In some analysis, only HARS total scores were used.

Data were analyzed using SPSS (Statistical Program for Social Sciences Inc., Chicago, IL, USA) version 11.5 software pack. Kruskal-Wallis and Mann-Whitney U tests were used for one by one assessment of 16 different parameters. In addition, logistic regression analysis with retrospective stepwise elimination of factors that were thought to be effective on anxiety was performed. Results were considered significant for $\mathrm{p}<0.05$.

The study was conducted with the approval of the Institutional Review Board.

\section{RESULTS}

Eighty-three of 205 patients (40.5\%) were male and 122 (59.5\%) were female. Anxiety was determined in 96 (46.8\%) of the patients.

Sociodemographic characteristics of the patients were compared according to anxiety levels and no significant relationships were found between frequency of anxiety and anxiety levels and age, marital status, education level, and monthly income. However, significant associations were found between anxiety and gender, health insurance and working status of the patients. Frequency of anxiety and total HARS scores were significantly higher in women compared to men $(\mathrm{p}<0.001)$ (Table 1). Frequency of anxiety and total HARS scores were also high in unemployed patients and in those with no health insurance.

No significant relationships were determined between anxiety and the complaints of patients being acute or chronic, patient awareness of the diagnosis, number of endoscopies applied previously, type of endoscopy, family history of gastrointesti- nal malignancies, and comorbid diseases. However, both anxiety frequency and total HARS scores were significantly high in patients with one psychiatric disease and in those with history of a previous unsatisfactory endoscopy (Table 1).

The factors found to be effective on anxiety levels according to single variable statistical analysis (gender, health insurance, working status, history of unsatisfactory endoscopy, and psychiatric disease) were assessed by multiple linear regression modality, and it was found that female gender increased the risk of state anxiety 4.5 fold $(p=0.024$, Odds Ratio $[\mathrm{OR}]=4.51,95 \%$ Confidence Interval $[\mathrm{CI}]=1.22-16.74$ ), presence of psychiatric disease increased the risk of state anxiety 8.6 fold ( $\mathrm{p}=0.001, \mathrm{OR}=8.56,95 \% \mathrm{CI}=3.35-21.86$ ), not working increased the risk of state anxiety 14.8 fold $(\mathrm{p}=0.016$, $\mathrm{OR}=14.80,95 \% \mathrm{CI}=1.67-131.40$ ), and history of an unsatisfactory endoscopy increased the risk of state anxiety 2.6 fold $(\mathrm{p}=0.007, \mathrm{OR}=2.58,95 \% \mathrm{CI}=1.28-5.20)$.

\section{DISCUSSION}

In the present study, we aimed to determine the frequency and level of state anxiety and related factors in patients referred for endoscopy, and it was found that state anxiety was higher in female patients and in those with psychiatric disease, unsatisfactory endoscopy history and no health insurance.

Anxiety is considered as one of the basic feelings in humans. All of us experience a level of anxiety in dangerous situations. State anxiety is a subjective fear that is felt in a stressful condition. The level of state anxiety increases if the stress level is high and decreases when the stress disappears (1). As with all other medical interventions, it is natural for patients to feel perturbed and restless before endoscopy. Nearly half (46.8\%) of all patients and most female patients (63.9\%) in our study group had state anxiety before undergoing endoscopy. Similar to our results, it was reported in many studies that frequency of state anxiety before endoscopy was higher in women than men. Tsai et al. (4) reported that female gender was a risk factor for state anxiety before colonoscopy. Ladas et al. (2) also found that anxiety was higher in women before colonoscopy. They also reported that history of previous colonoscopy had no effect on anxiety. We also found no relation between anxiety and the number of endoscopies applied previously. Similarly, Madan et al. (7) reported that anxiety scores were higher in women than men before endoscopy; however, they were similar after endoscopy. They also found that anxiety scores during endoscopy were related with scores before the procedure.

Anxiety levels of patients undergoing colonoscopy were found higher than in those undergoing gastroscopy by Baudet et al. (6). In our study, there were no significant relationships between anxiety and the complaints of patients being acute or chronic, patient awareness of the diagnosis and the type of 


\begin{tabular}{|c|c|c|c|c|c|c|}
\hline & N (\%) & $\begin{array}{l}\text { HARS } \\
\text { Score }\end{array}$ & $\mathrm{p}$ & $\begin{array}{c}\text { No Anxiety } \\
\text { n (\%) }\end{array}$ & $\begin{array}{l}\text { Anxiety } \\
\text { n (\%) }\end{array}$ & $\mathrm{p}$ \\
\hline Age & & & 0.918 & & & \\
\hline $15-20$ years & $8(3.9)$ & $4.6 \pm 2.2$ & & $4(3.7)$ & $4(4.2)$ & - \\
\hline $21-40$ years & $83(40.5)$ & $5.3 \pm 3.3$ & & $40(36.7)$ & $43(44.8)$ & 0.922 \\
\hline 41-65 years & $87(42.4)$ & $5.0 \pm 3.1$ & & $47(43.1)$ & $40(41.7)$ & 0.827 \\
\hline$>65$ years & $27(13.2)$ & $4.7 \pm 2.6$ & & $18(16.5)$ & $9 \quad(9.4)$ & 0.396 \\
\hline Gender & & & $<0.001$ & & & \\
\hline Male & $83(40.5)$ & $3.5 \pm 2.5$ & & $65(59.6)$ & 18 (18.8) & - \\
\hline Female & $122(59.5)$ & $6.1 \pm 3.0$ & & $44(40.4)$ & $78(81.3)$ & $<0.001$ \\
\hline Marital Status & & & 0.491 & & & \\
\hline Single & $23(11.2)$ & $4.4 \pm 3.4$ & & $14(12.8)$ & $9(9.8)$ & - \\
\hline Widow - Divorced & $16 \quad(7.8)$ & $5.1 \pm 2.6$ & & $8(7.3)$ & $8(8.3)$ & 0.502 \\
\hline Married & $166(81.0)$ & $5.2 \pm 3.1$ & & $87(79.8)$ & 79 (82.3) & 0.447 \\
\hline Educational level & & & 0.224 & & & \\
\hline Illiterate & $39(19.0)$ & $5.9 \pm 2.9$ & & $17(15.6)$ & $22(22.9)$ & 0.190 \\
\hline Primary school & $98(47.8)$ & $4.9 \pm 3.0$ & & $54(49.5)$ & $44(45.8)$ & 0.519 \\
\hline Secondary school & $17 \quad(8.3)$ & $5.2 \pm 3.1$ & & 9 (8.3) & $8 \quad(8.3)$ & 0.525 \\
\hline High school & $37(18.0)$ & $4.9 \pm 3.2$ & & $20(18.3)$ & $17(17.7)$ & 0.512 \\
\hline University & $14 \quad(6.8)$ & $4.1 \pm 3.7$ & & 9 (8.3) & $5(5.2)$ & - \\
\hline Health insurance & & & 0.038 & & & \\
\hline Available & $3(1.5)$ & $8.7 \pm 1.5$ & & - & $3(3.1)$ & - \\
\hline Not available & $202(98.5)$ & $5.0 \pm 3.1$ & & $109(100.0)$ & $93(96.9)$ & 0.101 \\
\hline Working status & & & $<0.001$ & & & \\
\hline Working & $56(27.4)$ & $3.7 \pm 2.5$ & & $38(34.9)$ & $18(18.8)$ & 0.016 \\
\hline Not working & $161(78.5)$ & $5.3 \pm 2.6$ & & $71(65.1)$ & $78(81.2)$ & $<0.001$ \\
\hline Monthly income & & & 0.269 & & & \\
\hline$<500 \mathrm{TL}$ & $59(28.8)$ & $5.4 \pm 3.0$ & & $29(26.6)$ & $30(31.3)$ & 0.649 \\
\hline 500-1000 TL & $107(52.2)$ & $5.1 \pm 3.1$ & & $59(54.1)$ & $48(50.0)$ & 0.889 \\
\hline$>1000 \mathrm{TL}$ & $39(19.0)$ & $4.5 \pm 3.1$ & & $21(19.3)$ & $18(18.8)$ & - \\
\hline Complaints & & & 0.325 & & & \\
\hline Chronic & $145(70.7)$ & $4.9 \pm 3.0$ & & $79(72.5)$ & $66(68.8)$ & - \\
\hline Acute & $60(29.3)$ & $5.3 \pm 3.3$ & & $30(27.5)$ & $30(31.3)$ & 0.558 \\
\hline Knows diagnosis & & & 0.886 & & & \\
\hline No & $171(83.4)$ & $5.1 \pm 3.0$ & & $92(84.4)$ & $79(82.3)$ & - \\
\hline Yes & $34 \quad(16.6)$ & $5.1 \pm 3.6$ & & $17(15.6)$ & $17(17.7)$ & 0.685 \\
\hline Previous endoscopies & & & 0.269 & & & \\
\hline None & $124(60.5)$ & $4.8 \pm 3.1$ & & $70(64.2)$ & $54(56.3)$ & - \\
\hline Once & $56(27.3)$ & $5.4 \pm 2.8$ & & $27(24.8)$ & $29(30.2)$ & 0.306 \\
\hline More than once & $25(12.2)$ & $5.6 \pm 3.3$ & & $12(11.0)$ & $13(13.5)$ & 0.440 \\
\hline Type of endoscopy & & & 0.107 & & & \\
\hline Gastroduodenoscopy & $120(58.5)$ & $5.5 \pm 3.2$ & & $57(52.3)$ & $63(65.6)$ & 0.441 \\
\hline Colonoscopy & $60(29.3)$ & $4.6 \pm 2.9$ & & $38(34.9)$ & $22(22.9)$ & 0.528 \\
\hline Rectoscopy & $25(12.2)$ & $4.3 \pm 2.7$ & & $14(12.8)$ & $11(11.5)$ & - \\
\hline Unsatisfactory endoscopy & & & $<0.001$ & & & \\
\hline No & $162(79.0)$ & $4.7 \pm 3.0$ & & $94(86.2)$ & $68(70.8)$ & - \\
\hline Yes & $43(21.0)$ & $6.4 \pm 3.1$ & & $15(13.8)$ & $28(29.2)$ & 0.007 \\
\hline Family history of GIS Ca & & & 0.078 & & & \\
\hline No & $173(84.4)$ & $4.9 \pm 3.1$ & & $96(88.1)$ & $77(80.2)$ & - \\
\hline Yes & $32(15.6)$ & $5.8 \pm 2.6$ & & $13(11.9)$ & $19(19.8)$ & 0.122 \\
\hline Psychiatric disease & & & $<0.001$ & & & \\
\hline No & $155(75.6)$ & $4.3 \pm 2.8$ & & $101(92.7)$ & $54(56.3)$ & - \\
\hline Yes & $50(24.4)$ & $7.4 \pm 2.6$ & & $8 \quad(7.3)$ & $42(43.8)$ & $<0.001$ \\
\hline Comorbid disease & & & 0.941 & & & \\
\hline No & $84(41.0)$ & $5.1 \pm 3.1$ & & $45(41.3)$ & $39(40.6)$ & - \\
\hline Yes & $121(59.0)$ & $5.1 \pm 3.0$ & & $64(58.7)$ & $57(59.4)$ & 0.924 \\
\hline
\end{tabular}


endoscopy applied. On the other hand, anxiety levels were found high in patients with unsatisfactory endoscopy history. Gebbensleben et al. (5) also reported higher scores in patients with unsatisfactory endoscopy history than in those without such a history. Jones et al. (9) assessed baseline anxiety levels of patients regardless of the endoscopy process by using State-Trait Anxiety Index, and then the scale was repeated just before the process. At the end of the study, they concluded that anxiety levels of patients who had high baseline anxiety were higher before endoscopy than in those with normal baseline anxiety levels. They also found no relations between anxiety and gender and age. We did not find any relation between anxiety and age, but found a relation between anxiety and gender. The relation found between state anxiety and psychiatric disease history in our study can be associated with the results of Jones et al. (9) if baseline anxiety is considered as a psychiatric disorder.

\section{REFERENCES}

1. Öner N, Lecompte A. Durumluk/Sürekli Kaygı Envanteri El Kitabı, 2. Basım. Istanbul: Boğaziçi Üniversitesi Yayınevi, 1998: 1-26.

2. Ladas SD. Factors predicting the possibility of conducting colonoscopy without sedation. Endoscopy 2000;32:688-92.

3. Eberhardt J, Van Wersch A, Van Schaik P, Cann P. Information, social support and anxiety before gastrointestinal endoscopy. Br J Health Psychol 2006;11:551-9.

4. Tsai MS, Su YH, Liang JT, Lai HS, Lee PH. Patient factors predicting the completion of sedation-free colonoscopy. Hepatogastroenterology 2008; 55:1606-8.

5. Gebbensleben B, Rohde H. Angst vor der gastrointestinalen Endoscopie ein bedeutsames Problem? Deutsche Medizinische Wochenschrift 1990; 115:1539-44.
In our study, anxiety frequency and anxiety levels were significantly lower in patients who had health insurance than in those did not. Only 1.5\% of the patients had no health insurance, but anxiety was determined in all of them. In addition, we found higher anxiety scores in patients who were unemployed. These patients may have more concerns about health expenditure and this can be considered to contribute to state anxiety.

\section{CONCLUSION}

Female gender, presence of psychiatric disease and unsatisfactory endoscopy history and having no health insurance were found as risk factors for state anxiety in patients referred for endoscopy. We think that consideration of these factors before endoscopic interventions may be useful for improving both patient and physician comfort.

6. Baudet JS, Borque P, Borja E, et al. Use of sedation in gastrointestinal endoscopy: a nationwide survey in Spain. Eur J Gastroenterol Hepatol 2009;21: 882-8.

7. Madan A, Minocha A. Who is willing to undergo endoscopy without sedation: patients, nurses, or the physicians? South Med J 2004;97 :8005.

8. Hamilton M. The assessment of anxiety states by rating. Br J Med Psychol 1959; 32: 50-5.

9. Jones MP, Ebert CC, Sloan T, et al. Patient anxiety and elective gastrointestinal endoscopy. J Clin Gastroenterol 2004;38:35-40. 